\title{
Preparation of extemporaneous oral liquid in the hospital pharmacy
}

\author{
Márcio Robert Mattos da Silva ${ }^{1}$, Letícia Pereira Dysars ${ }^{1}$, Elisabete Pereira dos Santos ${ }^{1}$, \\ Eduardo Ricci Júnior ${ }^{\circledR 1 *}$
}

\author{
${ }^{I}$ College of Pharmacy, Galenic Development Laboratory (LADEG), Department of Medicine, \\ Federal University of Rio de Janeiro, Rio de Janeiro, RJ, Brazil
}

\begin{abstract}
At the hospital, the pharmacist is constantly challenged to prepare extemporaneous solutions from tablets, capsules or drug powder for patients unable to swallow, such as pediatric, elderly and patients that use nasoenteric and nasogastric tubes. The preparation of extemporaneous solutions from capsules, tablets and drug powder requires stability studies analysis. This article is a bibliographic review of preparation of extemporaneous oral liquid from solid oral dosage forms used in clinical practice. The selected articles contain all the information regarding manipulation techniques, pharmaceutical excipients, packaging, storage conditions and results of stability studies above $90 \%$ performed by HPLC analysis. In addition, a situational analysis of the strategies for the preparation of the extemporaneous solution was described to help the manipulator in the decision. The preparation of extemporaneous solution from solid oral dosage forms is based on information from official compendium or scientific literature, to ensure safe and effective manipulated medicine.
\end{abstract}

Keywords: Extemporaneous oral liquid. Stability. Hospital pharmacy.

\section{INTRODUCTION}

A large part of the therapeutic arsenal consists of solid oral dosage forms such as tablets and capsules available for most patients, including hospitalized patients. However, pediatric, elderly and patients that must receive medications via nasogastric or gastrostomy tubes are unable to swallow solid oral dosage forms. One way to solve this problem is the preparation of extemporaneous solutions from solid oral dosage forms commercially available in the national and international markets (pharmacy and hospital pharmacy), for example, through tablets trituration or capsules opening and subsequent addition of water or another vehicle. However, there is difficulty in masking the unpleasant taste of the solution and reach the uniformity of the dose ensuring the correct dose. In addition, information in the literature about stability, storage conditions, packaging and handling technique for the preparation of the extemporaneous formulations is limited.

The risk of preparation of oral liquid formulations, such as formulation failure, microbial contamination,

\footnotetext{
*Correspondence: E. Ricci-Júnior. Faculdade de Farmácia, Universidade Federal do Rio de Janeiro. Av. Carlos Chagas Filho, Ilha do Fundão, 21941-590 Rio de Janeiro - RJ, Brazil. E-mail: ricci@pharma.ufrj.br
}

calculation errors, starting materials, patient acceptability, health safety risks and associated clinical risk factors, according to the place of preparation. The highest risk occurs when oral liquid formulations are prepared in the wards for nursing technician. The risk in the preparation tends to decrease when pharmacists in compounding pharmacies prepare the oral liquid formulations. The risk is even lower when oral liquid formulations are prepared by the pharmaceutical industry and the products are licensed and registered in the regulatory agencies. The technical and clinical risks associated with extemporaneously prepared medicines are considered below (Jackson, Lowey, 2010):

1 - Formulation failure: All formulae used for extemporaneous preparation should be validated and have supporting stability data. Suitable sources include pharmacopoeia formulations, industry expert reports and published papers. The causes of oral liquid formulation failure can be complex, including physical incompatibilities, interaction drug and excipient and drug degradation (oxidation, photo-degradation, hydrolysis, dimerization, polymerization). 2 - Microbial contamination: Microbial contamination may pose a significant risk to immunocompromised patients. In addition, the products of microbial degradation can lead to chemical changes in the preparation. Microbial 
growth can cause preparation turbidity and unpleasant odor. The choice of preservative for a formulation needs to take into account a number of factors, including $\mathrm{pH}$, physical compatibility and the patient group. Oral liquid preparations without preservative should be stored in a refrigerator with a maximum shelf life of 7 days at 2-8 ${ }^{\circ} \mathrm{C}$ (Jackson, Lowey, 2010). 3 - Calculation errors: Calculation errors pose the greatest risk of causing serious patient harm and the greater the complexity of calculation required, the higher the risk of an error. Formulations should be kept as simple as possible and all calculations should be independently checked and documented on a worksheet (Jackson, Lowey, 2010). 4 - Starting materials: The toxicity of some ingredients is age-specific and they may be inappropriate for children. Alcohol has been linked to CNS-depressant and hypoglycemic effects. Pediatrics formulations containing sugars have been associated with dental cavities. 5 - Patient acceptability: Oral liquid formulation should be palatable with good presentation. There is a good argument that taste is crucial to achieving good compliance in children. 6 - Health and safety risks: The risks to the operator should also be considered. Hospital pharmacy should be equipped with laminar flow when handling hazardous products. Good manipulation practices should be put in place to eliminate the risk of cross-contamination. 7 - Associated clinical risk factors: The majority of patients that receive extemporaneously prepared oral liquid formulation tend to be from vulnerable patient groups like neonates, children and the elderly, who are either unaware of ill-effects associated with their treatment or who cannot communicate with their clinician. Pharmacists should take into account the patients who receive extemporaneous preparations and regularly review their condition to ensure the treatment is effective. Any issues should be documented and reported to the manufacturer as part of a pharmacovigillance action (Jackson, Lowey, 2010).

The lack of pediatric products available on the market is related to: 1 - very small size of pediatric market compared to adults, especially medicines used to treat hypertension, tuberculosis, neoplasias and acquired immunodeficiency syndrome (Glass, Haywood, 2006); 2 - difficulties in performing clinical trials in children (Méndez et al., 2006); 3 - slow financial return and 4 - high requirements proposed by regulatory agencies for the development and registration of pediatric medicines that discourage the pharmaceutical industry (Glass, Haywood, 2006; Méndez et al., 2006; Nahata, 1999; Jackson, Lowey, 2010).

The unavailability of pharmaceutical form and dosage for pediatric patients challenges the pharmacy manipulator to triturate the tablet and adjust the dosage to a solid form (capsule or sachet) or liquid form (solution or suspension) for oral use (Martinho, Guerreiro, Simon, 2010; Brion, Nunn, Rietour, 2003). Therefore, the tablet must be triturated and the dosage adjustment made for safe administration to the patient (Mcdevict, Gurst, Chen 1998; Horn, Kuhn, Kanga, 1999; Pinto, Barbosa 2008; Doningos, 2010). The pharmacist should perform an analysis before triturating the tablet to adjust the dose by turning it into powder which will be used to fill a capsule or to prepare in a liquid form. The trituration from tablet or modified release capsule (delayed or extendedrelease) causes immediate release of the dose after oral administration, with the risk of adverse effects, toxicity or even pharmacological action loss, if the drug is sensitive to destruction by stomach acidity (Glass, Haywood, 2006; Nahata, 1999). The use of injectable solution for the preparation of the oral liquid solution is discouraged due to some of the following problems: drug or vehicle with mucosal, vesicant and irritant (Firas et al., 2016), extensive hepatic metabolism may reduce the bioavailability of the drug at subtherapeutic concentrations (Woods, 1997), drug with very low absorption in the intestinal mucosa (Hailong et al., 2014) and stomach acid and digestive enzymes may degrade the drug avoiding intestinal absorption (Perera et al., 2009).

Health professionals in pediatric hospitals usually promote tablets trituration in a mortar or capsules opening by dissolving the powder in single syrup or sorbitol mixture (Nahata, 1999). When an oral medicine is formulated for pediatric use, several factors should be considered, such as; gastrointestinal tract immaturity, reduced biliary secretion, and slow gastric emptying that may alter the absorption of many drugs (Glass, Haywood, 2006; Méndez et al., 2006). Many excipients such as preservatives, sweeteners and co-solvents of oral liquid formulations can cause problems for neonates.

Benzyl-alcohol syndrome has since become a recognized event in premature infants (Brown, Buist, Gepson, 1982). The normal metabolic pathways for benzyl- alcohol in adults are immature in premature infants, leading to the accumulation of benzyl-alcohol and benzoic acid. One of the most common preservative systems used is a combination of hydroxybenzoates also known as parabens. This preservative system can worsen asthma and has also been shown to promote hypersensitivity reactions (Golightly et al., 1988). Propylene glycol may also acts as an osmotic laxative. Preparations that contain large quantities may not, therefore, be suitable for neonates and young children. Ethanol is known to have a CNS depressant effect, and its use is avoided wherever 
possible in extemporaneous preparations. However, limited quantities of ethanol may be justifiable under some circumstances, in order to prevent the use of other co-solvent systems associated with known toxicities. The use of preparations that contain sugars, especially sucrose, are associated with the formation of dental cavities, particularly with long-term use (Jackson, Lowey, 2010). Table I summarizes some excipients that when administered to pediatric patients may possibly cause rash, contact dermatitis, angio dermatitis and respiratory syndrome, allergic reactions, adverse effects in patients intolerant to fructose with hypoglycemic effects, liver damage and coma, diarrhea due to the osmotic effect, lactic acidosis, renal failure, central nervous system depression, hyperglycemia in diabetic patients and cavities and others (WHO, 2011a; Cuzzolin, 2018; EMEA, 2013; Jackson, Lowey, 2010).

The elderly population and children have difficulty in ingestion of solid oral dosage forms. Thus, caregivers of elderly and hospital nurses usually promote tablets trituration and sprinkle powders on food. The aim of this practice is to supply the necessary medicines to elderly patients and children; however, there are problems in this practice. Administration of triturated tablets with food is worrisome due to the physical-chemical interaction of the drug in the stomach acid environment. Simultaneous trituration of various types of tablets should be avoided to prevent pharmacodynamic and pharmacokinetic problems (Rasgado, 2009; Paradiso, 2002).

Administration of a solid oral dosage form through nasogastric tube needs transformation into oral liquid form using a suitable vehicle, for example; aqueous solution with low viscosity to prevent the clogging of nasogastric tube. The use of nasogastric tube for drugs administration may alter the bioavailability of the drug through its interaction with the material constituting the nasogastric tube. In addition, tablets trituration may produce particles or crystals by precipitation blocking the nasogastric tube. The knowledge of the interaction of the drug with the material constituting the nasogastric tube may avoid problems. Some drugs have affinity for the material constituting the nasogastric tube leading to the adsorption of the drug or the permeation to the tube decreasing the dose of the drug to the patient; for example carbamazepine, which is adsorbed on the nasogastric tube (Rebecca, Vicky, 2015; Silva, Lisboa, 2011; Hoefler, Vidal, 2009; Willians, 2008). Delayedrelease tablets, capsule-containing granules with gastroresistant coating, sustained-release and controlledrelease tablets should not be triturated (Table II). The gastro-resistant dosage forms for intestinal release
TABLE I - Some excipients, when administered to pediatric patients, may cause health risk (WHO, 2011a; Cuzzolin, 2018; EMEA, 2013; Jackson, Lowey, 2010)

\begin{tabular}{|c|c|}
\hline Excipients & $\begin{array}{l}\text { Inherent risk for the } \\
\text { pediatric patient }\end{array}$ \\
\hline $\begin{array}{l}\text { Benzyl Alcohol, Benzoic } \\
\text { acid and Sodium benzoate }\end{array}$ & $\begin{array}{l}\text { Children less than } 3 \text { years old } \\
\text { may develop rash, contact } \\
\text { dermatitis, angiodermatitis and } \\
\text { respiratory syndrome. }\end{array}$ \\
\hline Dye & Allergic and other reactions. \\
\hline $\begin{array}{l}\text { Sodium cyclamate and } \\
\text { Saccharin sodium }\end{array}$ & $\begin{array}{l}\text { High sodium concentrates } \\
\text { are not recommended for } \\
\text { hypertensive and renal } \\
\text { patients. }\end{array}$ \\
\hline Ethanol & $\begin{array}{c}\text { Depression of the central } \\
\text { nervous system }\end{array}$ \\
\hline $\begin{array}{l}\text { Methylpaben and } \\
\text { Propylparaben }\end{array}$ & Elevation of bilirubin \\
\hline Propylene glycol & $\begin{array}{l}\text { Diarrhea due to osmotic } \\
\text { effect, lactic acidosis, renal } \\
\text { failure, central nervous system } \\
\text { depression. }\end{array}$ \\
\hline Polysorbate 80 & $\begin{array}{l}\text { Metabolic acidosis, liver } \\
\text { dysfunction and cholestasis. }\end{array}$ \\
\hline Sucrose & $\begin{array}{l}\text { Hyperglycemia in diabetic } \\
\text { patients and cavities. }\end{array}$ \\
\hline Sorbitol & $\begin{array}{l}\text { Adverse effects in patients } \\
\text { intolerant to fructose with } \\
\text { hypoglycemic effects, liver } \\
\text { damage and coma. }\end{array}$ \\
\hline
\end{tabular}

when triturated and ingested with aqueous solution, exposes the drug to acidity of the stomach causing its inactivation. Trituration of an extended or controlled release tablet leads to immediate release of the drug exposing the patient to high dosages or exacerbation of adverse effects. Table II contains examples of solid oral dosage that should not be triturated. Information on the modified release systems of Table II are contained in the patient's information chart.

The objective of this work was to carry out a bibliographic review for preparation of extemporaneous solutions from the solid oral dosage forms for use in clinical practice. The choice of drugs was based on the lack of extemporaneous oral liquid form. All selected articles contained the following terms: manipulation techniques, excipients, packaging, storage conditions and stability studies results above $90 \%$ analyzed by HPLC. 
TABLE II - Oral solid pharmaceutical forms that cannot be triturated and modified

\begin{tabular}{|c|c|c|c|}
\hline Medicines & Drug & Pharmaceutical form & Comments \\
\hline Actonel & Risedronate & Film-coated tablet & $\begin{array}{c}\text { Tablets, when triturated, may cause } \\
\text { oropharyngeal irritation }\end{array}$ \\
\hline Adalat OROS & Nifedipine & Osmotic pump tablet & Extended-release tablet \\
\hline Allegra D & $\begin{array}{l}\text { Fexofenadine hydrochloride and } \\
\text { Pseudoephedrine hydrochloride }\end{array}$ & Film-coated tablet & Extended-release tablet \\
\hline Cardizem & Diltiazem hydrochloride & Tablet & Extended-release coating tablet \\
\hline Cardizem CD & Diltiazem hydrochloride & Capsule & Extended-release tablet \\
\hline Cipro XR & Ciprofloxacin & Film-coated tablet & Extended-release tablet \\
\hline Claritin D & Loratadine and Pseudoephedrine & Tablet & Extended-release tablet \\
\hline Claritin D 24h & Loratadine and Pseudoephedrine & Film-coated tablet & Extended-release tablet \\
\hline Depakene & Valproic acid & Capsule & $\begin{array}{l}\text { Extended-release tablet. When } \\
\text { triturated, may causes mucous } \\
\text { irritation }\end{array}$ \\
\hline Erythromycin stearate & Erythromycin stearate & Tablet & Enteric coating for delayed release \\
\hline Feldene & Piroxicam & Capsule & Irritant of mucous \\
\hline Isordil sublingual & Isosorbide & Tablet (sublingual) & Not triturate. Sublingual release \\
\hline Isotretinoin & Isotretinoin & Capsule & Not open. Irritant to mucous \\
\hline Kaletra & Lopinavir and Ritonavir & Tablet & $\begin{array}{c}\text { Film-coated to prevent direct } \\
\text { patient contact with drugs to avoid } \\
\text { cross-contamination }\end{array}$ \\
\hline Metri & Nicotinic acid & Film-coated tablet & Extended-release tablet \\
\hline Ritalina La & Methylphenidate & Capsule & Extended-release tablet \\
\hline Xanax XR & Alprazolam & Tablet & Extended-release tablet \\
\hline XigDuo XR & $\begin{array}{l}\text { Dapagliflozin }+ \text { metformin } \\
\text { hydrochloride }\end{array}$ & Film-coated tablet & Extended-release tablet \\
\hline
\end{tabular}

\section{Methodology}

A literature review was carried out observing publications available in the Medline (International Literature in Health Sciences), Lilacs (Latin American and Caribbean in Health Sciences) and Scientific Electronic Library Online (SCIELO) databases between 1990 and 2017. The terms used were: "extemporaneous formulations", "extemporaneous oral liquid", "extemporaneous preparation", "stability of extemporaneous formulations", "extemporaneous preparation for children", "medication administration through enteral feeding". After reading abstracts of the collected papers, only articles containing the preparation method, materials and stability studies of extemporaneous solutions from solid oral dosage forms commercially available were selected. Because it is the most common situation found in clinical practice.

\section{RESULTS AND DISCUSSION}

Results of the bibliographic review are described below, demonstrating the most common preparation of extemporaneous solutions from solid oral dosage forms used in clinical practice. The selected articles contain all the information regarding manipulation techniques, excipients, packaging, storage conditions and stability studies results above $90 \%$ performed by HPLC analysis. Table III contains preparations of extemporaneous solutions from solid oral dosage forms commercially available, mentioning the drug, storage conditions, stability and references. Details from descriptions of the preparation method, pharmaceutical excipients and packaging are described through viewing the selected articles. Some drugs have been selected for a detailed description such as: captopril, carvedilol, diltiazem, enalapril, lisinopril, metoprolol, moxifloxacin, 
TABLE III - Extemporaneous oral liquid prepared from solid oral dosage forms commercially available

\begin{tabular}{|c|c|c|}
\hline Drug & Stability of liquid oral form & References \\
\hline Acetazolamide & 60 days at $25^{\circ} \mathrm{C}$ and $40^{\circ} \mathrm{C}$ & Santoveña et al., 2016b \\
\hline Alprazolam & 60 days at $25^{\circ} \mathrm{C}$ & Allen, Erickson, 1998 \\
\hline Amlodipine & 1 year at $4{ }^{\circ} \mathrm{C}$ in absence of light & Vossen et al., 2016 \\
\hline Aripiprazole & 91 days at $4{ }^{\circ} \mathrm{C}$ & Pramann et al., 2016 \\
\hline Atorvastatin & 30 days at $8^{\circ} \mathrm{C}$ or $25^{\circ} \mathrm{C}$ & Zaid et al., 2016 \\
\hline Bosentan & 31 days at $21-26^{\circ} \mathrm{C}$ & Malik et al., 2016 \\
\hline Capecitabina & 14 days at $8^{\circ} \mathrm{C}$ in absence of light & Romero et al., 2016 \\
\hline Captopril & 45 days at $5^{\circ} \mathrm{C}$ & Dysarz, 2017 \\
\hline Carbidopa & 30 days at $20-25^{\circ} \mathrm{C}$ and 90 days at $2-8{ }^{\circ} \mathrm{C}$ & Polonini et al., 2016b \\
\hline Carvedilol & 8 weeks at $22-26^{\circ} \mathrm{C}$ or $4-8^{\circ} \mathrm{C}$ & Yamreudeewon, Dolence, Pahl, 2006 \\
\hline Celecoxib & 90 days at $40^{\circ} \mathrm{C}$ & Kiel et al., 2016 \\
\hline Chloroquine & 90 days at $2-8{ }^{\circ} \mathrm{C}$ or $20-25^{\circ} \mathrm{C}$ & Ferreira et al., 2016 \\
\hline Chlorpromazine & 90 days at $2-8^{\circ} \mathrm{C}$ or $22-25^{\circ} \mathrm{C}$ & Prohotsky, Juba, Zhao, 2014 \\
\hline Cinacalcet & 64 days at $2-8^{\circ} \mathrm{C}$ or $22-25^{\circ} \mathrm{C}$ in absence of light & Thomson, Hutchinson, Chablani, 2018 \\
\hline Cholecalciferol & 90 days at $2-8^{\circ} \mathrm{C}$ or $20-25^{\circ} \mathrm{C}$ & Polonini et al., 2016b \\
\hline Clobazam & 56 days at $4^{\circ} \mathrm{C}$ or $25^{\circ} \mathrm{C}$ & Buontempoa et al.,2013 \\
\hline Clomipramine & 90 days at $5^{\circ} \mathrm{C}$ or $25^{\circ} \mathrm{C}$ & Polonini et al., 2016a \\
\hline Clonazepam & 60 days at $5^{\circ} \mathrm{C}$ or $25^{\circ} \mathrm{C}$ & Allen, Erickson, 1996b \\
\hline Clonidine & 91 days at $4{ }^{\circ} \mathrm{C}$ or $25^{\circ} \mathrm{C}$ & $\begin{array}{l}\text { Ma, Decarie, Ensom, 2014; } \\
\text { Ensom, Decarie, } 2014\end{array}$ \\
\hline Dapsone & 91 days at $4{ }^{\circ} \mathrm{C}$ or $25^{\circ} \mathrm{C}$ & Nahata, Morosco, Trowbridge, 2000 \\
\hline Diazoxide & 90 days $5^{\circ} \mathrm{C}$ or $25^{\circ} \mathrm{C}$ in absence of light & Friciu et al., $2016 \mathrm{~b}$ \\
\hline Diltiazem & 60 days at $5^{\circ} \mathrm{C}$ or $25^{\circ} \mathrm{C}$ & Allen, Erickson, 1996a \\
\hline Enalapril & 30 days at $25^{\circ} \mathrm{C}$ in absence of light & Sosnowska, 2009 \\
\hline Erlotinib & 28 days at $25^{\circ} \mathrm{C}$ in absence of light & Li et al., 2016 \\
\hline Flecainide & 30 days at $25^{\circ} \mathrm{C}$ in absence of light & Santoveña et al., 2016a \\
\hline Folicacid & 90 days at $5^{\circ} \mathrm{C}$ and $25^{\circ} \mathrm{C}$ & Polonini et al., 2016a \\
\hline Furosemide & 270 days at $25^{\circ} \mathrm{C}$ at $40^{\circ} \mathrm{C}$ & Zahálka et al., 2017 \\
\hline Gabapentin & 90 days at $25^{\circ} \mathrm{C}$ & Friciu, Roullin, Leclair, 2017 \\
\hline Glibenclamide & 90 days at $4{ }^{\circ} \mathrm{C}, 25^{\circ} \mathrm{C}$ or $40^{\circ} \mathrm{C}$ & Estevez et al., 2016 \\
\hline Haloperidol & 90 days at $2-8^{\circ} \mathrm{C}$ or $22-25^{\circ} \mathrm{C}$ & Polonini et al., 2016b \\
\hline Hydrochlorothiazide & 90 days at $5^{\circ} \mathrm{C}$ or $25^{\circ} \mathrm{C}$ & Poloniniet al., 2016a \\
\hline Idebenone & 90 days at $5{ }^{\circ} \mathrm{C}$ or $25^{\circ} \mathrm{C}$ in absence of light & Schlatter et al, 2017 \\
\hline Imatinib & 14 days at $5{ }^{\circ} \mathrm{C}$ or $25^{\circ} \mathrm{C}$ in light or absence of light & Li et al., 2016 \\
\hline Imipramine & 90 days at $2-8^{\circ} \mathrm{C}$ or $22-25^{\circ} \mathrm{C}$ & Polonini et al., 2016b \\
\hline Isotretinoin & 6 months at $40-42^{\circ} \mathrm{C}$ & Montwani, Isloor, Arora, 2015 \\
\hline Lapatinib & 28 days at $25^{\circ} \mathrm{C}$ & Li et al., 2016 \\
\hline Levodopa & 30 days at $20-25^{\circ} \mathrm{C}$ and 90 days at $2-8^{\circ} \mathrm{C}$ & Polonini et al., 2016b \\
\hline Levofloxacin & 57 days at $23-25^{\circ} \mathrm{C}$ & Vanden Bussche et al., 1999 \\
\hline Lisinopril & 4 weeks at $\leq 25^{\circ} \mathrm{C}$ & Thompson et al., 2003 \\
\hline Loperamide & 90 days at $5^{\circ} \mathrm{C}$ or $25^{\circ} \mathrm{C}$ & Polonini et al., 2016a \\
\hline
\end{tabular}


TABLE III - Extemporaneous oral liquid prepared from solid oral dosage forms commercially available (cont.)

\begin{tabular}{|c|c|c|}
\hline Drug & Stability of liquid oral form & References \\
\hline Lorazepam & 60 days at $22-25^{\circ} \mathrm{C}$ & Polonini et al., $2016 \mathrm{~b}$ \\
\hline Melatonin & 90 days at $3-5^{\circ} \mathrm{C}$ and $23-27^{\circ} \mathrm{C}$ & Friciu et al., 2016a \\
\hline Metformin & 30 days at $4-40^{\circ} \mathrm{C}$ in the presence or absence of light & Alemon-Medina et al., 2014 \\
\hline Methadone & 90 days at $4{ }^{\circ} \mathrm{C}$ and $25^{\circ} \mathrm{C}$ & Provenza et al., 2016 \\
\hline Methotrexate & 90 days at $5{ }^{\circ} \mathrm{C}$ or $25^{\circ} \mathrm{C}$ & Polonini et al., $2016^{\mathrm{a}}$ \\
\hline Metoprolol & 8 weeks at $22-26^{\circ} \mathrm{C}$ or $4-8^{\circ} \mathrm{C}$ & Yamreudeewong, Dolence, Pahl, 2006 \\
\hline Minocycline & 10 days at $2-8^{\circ} \mathrm{C}$ or $22-25^{\circ} \mathrm{C}$ & Polonini et al., 2016b \\
\hline Minoxidil & 10 weeks at $2-4^{\circ} \mathrm{C}$ in absence of light & Song et al., 2018 \\
\hline Moxifloxacin & 90 days at $23-25^{\circ} \mathrm{C}$ & Hutchinson, Johnson, Klein, 2009 \\
\hline Nadolol & 90 days at $5^{\circ} \mathrm{C}$ or $25^{\circ} \mathrm{C}$ & Polonini et al. 2016a \\
\hline Naltrexone & 90 days at $5{ }^{\circ} \mathrm{C}$ or $25^{\circ} \mathrm{C}$ & Polonini et al., 2016a \\
\hline Naproxen & 91 days at $4{ }^{\circ} \mathrm{C}$ and $25^{\circ} \mathrm{C}$ & Ensom, Decarie, Lingertat-Walsh, 2015 \\
\hline Norfloxacin & 56 days at $23-25^{\circ} \mathrm{C}$ & Johnson, Price, Hession, 2001 \\
\hline Oseltamivir & 35 days at $5^{\circ} \mathrm{C}$ or $25^{\circ} \mathrm{C}$ or 13 days at $30^{\circ} \mathrm{C}$ & Winiarski et al., 2007 \\
\hline Pentoxifylline & 90 days at $5^{\circ} \mathrm{C}$ or $25^{\circ} \mathrm{C}$ & Polonini et al., 2016 \\
\hline Phenobarbital & 60 days at $4{ }^{\circ} \mathrm{C}$ and 30 days at $25^{\circ} \mathrm{C}$ & Provenza et al., 2016 \\
\hline Phenytoin & 90 days at $2-8{ }^{\circ} \mathrm{C}$ or $20-25^{\circ} \mathrm{C}$ & Ferreira et al., 2016 \\
\hline Propafenone & 90 days at $3-5^{\circ} \mathrm{C}$ or $15 \pm 5^{\circ} \mathrm{C}$ & Olguín, 2008 \\
\hline Propranolol & 120 days at $25^{\circ} \mathrm{C}$ and $4{ }^{\circ} \mathrm{C}$ & Ensom et al., 2013 \\
\hline Pyridoxine & 90 days at $2-8^{\circ} \mathrm{C}$ or $20-25^{\circ} \mathrm{C}$ & Ferreira et al., 2016 \\
\hline Quinapril & 6 weeks at $5^{\circ} \mathrm{C}$ & Freed et al., 2005 \\
\hline Ribavirin & 28 days at $4{ }^{\circ} \mathrm{C}$ & Chan, Tong, Chow, 2004 \\
\hline Saquinavir & 20 days at $5^{\circ} \mathrm{C}$ or $25^{\circ} \mathrm{C}$ & Tan, Thenmozhiyal, Ho, 2003 \\
\hline Sildenafil & 91 days at $4{ }^{\circ} \mathrm{C}$ or $25^{\circ} \mathrm{C}$ & Nahata, Morosco, Brady, 2006 \\
\hline Sotalol & 180 days at $5^{\circ} \mathrm{C}$ or $25^{\circ} \mathrm{C}$ in absence of light & Klovrzová et al., 2016 \\
\hline Sulfadiazine & 90 days at $2-8^{\circ} \mathrm{C}$ or $20-25^{\circ} \mathrm{C}$ & Ferreira et al., 2016 \\
\hline Sulfasalazine & 90 days at $2-8^{\circ} \mathrm{C}$ or $20-25^{\circ} \mathrm{C}$ & Ferreira et al., 2016 \\
\hline Tacrolimus & 90 days at $2-8^{\circ} \mathrm{C}$ or $22-25^{\circ} \mathrm{C}$ & Polonini et al., 2016b \\
\hline Terbinafine & 90 days at $2-8^{\circ} \mathrm{C}$ or $22-25^{\circ} \mathrm{C}$ & Polonini et al., 2016b \\
\hline Tetracycline & 90 days at $2-8^{\circ} \mathrm{C}$ or $20-25^{\circ} \mathrm{C}$ & Ferreira et al., 2016 \\
\hline Tiagabine & 70 days at $25^{\circ} \mathrm{C}$ & Nahata, Morosco, 2003 \\
\hline Topiramate & 90 days at $2-8^{\circ} \mathrm{C}$ & Allen, 2017 \\
\hline Trimethoprim & 90 days at $2-8^{\circ} \mathrm{C}$ at $20-25^{\circ} \mathrm{C}$ & Ferreira et al., 2016 \\
\hline Vancomycin & 91 days at $4{ }^{\circ} \mathrm{C}$ or $25^{\circ} \mathrm{C}$ & Smith et al., 2017 \\
\hline Valsartan & 90 days at $2-8^{\circ} \mathrm{C}$ or $22-25^{\circ} \mathrm{C}$ & Polonini et al., 2016b \\
\hline Warfarin & 30 days at $25^{\circ} \mathrm{C}$ and 45 days at $4{ }^{\circ} \mathrm{C}$ & Schlatter, Cisternino, 2017 \\
\hline Zonisamide & 90 days at $2-8^{\circ} \mathrm{C}$ or $20-25^{\circ} \mathrm{C}$ & Ferreira et al., 2016 \\
\hline
\end{tabular}

propafenone and ribavirin. These medications were selected as being the most commonly dispensed in clinical practice, in accordance with extensive bibliographic review from literature.
All oral liquid formulations with stability $>$ $90 \%$ were considered. Content and stability $(\%)$ were determined by HPLC (High performance liquid chromatography),metoprolol 


\section{Captopril}

Captopril was the first angiotensin converting enzyme (ACE) inhibitor that was marketed. Administered orally, it is rapidly absorbed and has a bioavailability of about $75 \%$. It is widely used in the treatment of hypertension, cardiac insufficiency, myocardial infarction and diabetic nephropathy in patients with insulin-dependent diabetes mellitus (Dysarz, 2017). In the Brazilian market, this drug is only available in the solid oral dosage form (tablets). In a work performed by Dysarz (2017), it was developed an extemporaneous solution of captopril $(5 \mathrm{mg} / \mathrm{mL})$ and the stability of the extemporaneous solution evaluated. The formulation containing captopril $(5 \mathrm{mg} / \mathrm{mL})$, EDTA, sodium saccharin and water stored in amber glass bottles and stored at $5{ }^{\circ} \mathrm{C}$ refrigerator temperature was stable for 45 days maintaining the content of the drug $(>90 \%)$ and degradation product within the Brazilian pharmacopoeia limits (Dysarz, 2017). The stability of $0.75 \mathrm{mg} / \mathrm{mL}$ captopril extemporaneous oral liquid prepared from tablet was studied by Allen and Erickson. One tablet of $100 \mathrm{mg}$ was pulverized and the powder comminuted in a mortar with a pestle. The vehicle used was a 1:1 mixture of Ora-Sweet:Ora-Plus and 1:1 mixture of Ora-Sweet SF:Ora-Plus, both with initial $\mathrm{pH}$ of 4.1 . The quantity of vehicle was qs $134 \mathrm{~mL}$. A portion of the vehicle was used to levigate the powder and a uniform paste prepared. Additional vehicle was added to the mortar in small portions and rinsed repeatedly. The product was placed in an amber clear plastic (polyethylene terephthalate) and fitted with caps lined with low-density polyethylene foam. Three bottles were stored at $5{ }^{\circ} \mathrm{C}$ and three bottles at $25^{\circ}$ in the absence of light. The samples were analyzed from each individual bottle after 1, 2, 7, 10, 14, 28, 35 and 60 days. The oral liquids were examined at each sample time and there was no change in appearance or odor. The solution remained stable for 7 days at $25^{\circ} \mathrm{C}$ or 14 days at $5{ }^{\circ} \mathrm{C}$ for the Ora-Sweet:Ora-Plus vehicle and 5 days at $25^{\circ} \mathrm{C}$ or 10 days at $5{ }^{\circ} \mathrm{C}$ for the Ora-Sweet SF and Ora-Plus. The concentration of captopril found was above $90 \%$ (Allen, Erickson, 1996a).

\section{Enalapril}

Sosnowska et al. investigated the stability of $0.1 \mathrm{mg} / \mathrm{mL}$ and $10 \mathrm{mg} / \mathrm{mL}$ enalapril maleate extemporaneous suspensions prepared from commercially available tablets. Enalapril maleate is a prodrug, with no direct biological activity. It is quickly absorbed after oral and hydrolyzed in vivo into its active form, enalaprilate, a potent inhibitor of the angiotensin converting enzyme
(ACE). It is widely used in adult and pediatric patients to treat hypertension and cardiac insufficiency. For the extemporaneous preparation the tablets were triturated to a fine powder and mixed with a solution of $0.5 \%$ hydroxyethyl cellulose, then, it was added a mixture of raspberry syrup and hydroxyethyl cellulose solution, 5\% (1:10). Raspberry syrup was used to mask the unpleasant taste of enalapril maleate. In both formulations $0.2 \%$ of methyl hydroxybenzoate was added as preservative. Enalapril maleate is stable at $\mathrm{pH}$ close to 3.0 , the $\mathrm{pH}$ values of the formulations were adjusted to 3.0 using citric acid $\left(1 \mathrm{~mol} \mathrm{~L}^{-1}\right)$. The suspensions were stored in amber glass flasks at $25^{\circ} \mathrm{C}$ in the absence of light. After 30 days of storage, the enalapril maleate concentration was $98 \%$ and there were no significant changes in viscosity and $\mathrm{pH}$ of the suspensions (Sosnowska, 2009). Allen and Erickson studied the stability of $1 \mathrm{mg} / \mathrm{mL}$ enalapril maleate extemporaneous oral liquid prepared from tablets. The extemporaneous oral liquids were prepared by tablet trituration and added in a 1:1 mixture of Ora-Sweet and Ora-Plus and 1:1 mixture of Ora-Sweet SF and Ora-Plus and placed in $120 \mathrm{~mL}$ amber, clear polyethylene terephthalate bottles. The extemporaneous oral liquids were stored at $25^{\circ} \mathrm{C}$ and $5{ }^{\circ} \mathrm{C}$, in the absence of light. After 60 days of storage, the enalapril maleate initial drug concentration was at least $91 \%$ and there were no substantial changes in the appearance, odor, or $\mathrm{pH}$ of any liquid observed (Allen, Erickson, 1998).

\section{Carvedilol}

In a study carried out by Yamreudeewonget, Dolence and Pahlthe (2006), the stability of extemporaneous solutions of carvedilol was analyzed. Carvedilol is a non-selective $\beta$-adrenergic receptor antagonist and a $\alpha 1$-selective $\alpha$-adrenergic receptor antagonist, and exhibits anti-anxiety properties. The drug is used in the treatment of congestive heart failure, angina pectoris and high blood pressure. The preparation method of extemporaneous solution of carvedilol $25 \mathrm{mg}$ was developed using three tablets of caverdilol $25 \mathrm{mg}$, which were triturated and mixed with $20 \mathrm{~mL}$ deionized water to form a paste. It was added $40 \mathrm{~mL}$ of $70 \%$ sorbitol solution and sufficient amount of deionized water to obtain a final volume of $120 \mathrm{~mL}$. The concentration of carvedilol in the mixture was approximately $0.625 \mathrm{mg} / \mathrm{mL}$. Part of the solution was stored in an amber PET bottle at $22-26^{\circ} \mathrm{C}$ and another part at $4-8{ }^{\circ} \mathrm{C}$. For eight weeks the solutions remained stable. The concentration of carvedilol found was $\pm 10 \%$ of the initial concentration (Yamreudeewonget, Dolence, Pahl, 2006). 


\section{Diltiazem}

Diltiazem hydrochloride is a calcium channel antagonist, used primarily to prevent angina pectoris, but it is also used in cases of coronary heart disease with tachycardia and arterial hypertension. Allen and Erickson (1996a) studied the stability of diltiazem hydrochloride solution $12 \mathrm{mg} / \mathrm{mL}$. Sixteen diltiazem hydrochloride tablets of $90 \mathrm{mg}$ were triturated and added to a mixture of $60 \mathrm{~mL}$ Ora-Sweet ${ }^{\circledR}$ and $60 \mathrm{~mL}$ Ora-Plus ${ }^{\circledR}(1: 1)$. The preparation was stored in amber PET bottles at $5{ }^{\circ} \mathrm{C}$ and $25^{\circ} \mathrm{C}$ in the absence of light. After 60 days, an average of at least $92 \%$ of the initial concentration of diltiazem hydrochloride remained stable in the preparation (Allen, Erickson, 1996a).

\section{Lisinopril}

Thompson et al. (2003) studied the stability of $1 \mathrm{mg} / \mathrm{mL}$ lisinopril suspension prepared from commercially available tablets. Lisinopril is an angiotensin converting enzyme (ACE) inhibitor and when administered orally the absorption is slow, variable and incomplete that is not reduced by the presence of food. Lisinopril is indicated for the treatment of hypertension, heart failure and postmyocardial infarction. The suspension was prepared by addition of purified water and the tablets previously triturated in amber polyethylene terephthalate (PET) bottle. The suspension was shaken by hand. Subsequently, the following vehicles were added gradually: Bicitra ${ }^{\circledR}$ and Ora-Sweet $\mathrm{SF}{ }^{\circledR}$, shaking the bottle after each addition. The suspension was stored at $25^{\circ} \mathrm{C}$ under ambient light. After 4 weeks of storage, the concentration of lisinopril was $99 \%$ (Thompson et al., 2003).

\section{Metoprolol}

Yamreudeewonget, Dolence and Pahlconducted (2006) analyzed the stability of extemporaneous solutions metoprolol tartrate prepared from tablets. Metoprolol tartrate is a selective antagonist of $\beta 1$-adrenergic receptors. It is widely used in the treatment of hypertension, angina pectoris, post-infarction, heart failure, cardiac arrhythmia, hyperthyroidism (as adjunctive medication) and in prophylaxis of migraine. To prepare the solution were used three tablets of metoprolol tartrate $100 \mathrm{mg}$, which were triturated in a mortar and $20 \mathrm{~mL}$ of deionized water was added to form a paste. After this first step, were added $80 \mathrm{~mL}$ of sorbitol solution $70 \%$ and deionized water to the volume of $240 \mathrm{~mL}$. The solution obtained was highly viscous and with a concentration of $1.25 \mathrm{mg} / \mathrm{mL}$ metoprolol tartrate. Part of the solution was stored in an amber PET bottle at $22-26{ }^{\circ} \mathrm{C}$ and another part at $4-8{ }^{\circ} \mathrm{C}$ for 8 weeks. During this period there was no significant decrease in metoprolol concentration in the extemporaneous solutions. The results found were $\pm 10 \%$ of the initial concentration (Yamreudeewonget, Dolence, Pahl, 2006).

\section{Moxifloxacin}

The stability of a $20 \mathrm{mg} / \mathrm{mL}$ moxifloxacin suspension was studied by Hutchinson, Johnson and Klein. To prepare the suspension, three moxifloxacin tablets $400 \mathrm{mg}$ were triturated using a mortar of glass until obtaining a fine powder. $30 \mathrm{~mL}$ of Ora-Plus ${ }^{\circledR}$ and Ora-Sweet ${ }^{\circledR}$ were added to the fine powder. The suspension was stored in an amber plastic bottle at $23-25^{\circ} \mathrm{C}$ for 90 days. At least $99 \%$ of the initial concentration of moxifloxacin remained stable for 90 days (Hutchinson, Johnson, Klein, 2009).

\section{Propafenone}

Propafenone is an antiarrhythmic drug indicated for the treatment of symptomatic supraventricular tachyarrhythmia. Studies indicate that propafenone is a relatively safe drug for supraventricular tachycardia in pediatric patients: however, the approval and admission of propafenone for clinical use in children are restricted due to the limited number of studies involving the pediatric population (Olguín, 2008). In a study carried out in Mexico by Olguín (2008); the stability of an extemporaneous suspension of $1.5 \mathrm{mg} / \mathrm{mL}$ propafenone was determined. To prepare the suspension, $150 \mathrm{mg}$ of propafenone tablet was triturated to a fine powder in a mortar, and then $100 \mathrm{~mL}$ of pomegranate syrup was added. The suspension was placed in an amber glass flask, where one flask was stored at $3-5^{\circ} \mathrm{C}$ and the other at $15 \pm 5^{\circ} \mathrm{C}$. In both storage conditions, the suspension remained stable for 90 days. The percentage of concentration of suspension storage at $3-5{ }^{\circ} \mathrm{C}$ was around $90 \%$ and for suspension storage at $15 \pm 5{ }^{\circ} \mathrm{C}$ it was above $90 \%$ (Olguín, 2008).

\section{Ribavirin}

Ribavirin is a synthetic nucleoside with structure similar to that of guanosine. This drug acts by altering the reservoirs of viral nucleotides or by interfering with the synthesis of viral messenger RNA. It is used to treat all forms of viral hepatitis and Lassa fever (Chan, Tong, Chow, 2004). In a study conducted by Chan, Tong and Chow, the stability of a $40 \mathrm{mg} / \mathrm{mL}$ ribavirin suspension 
was determined. To prepare the suspension, solutions of benzoic acid and hydroxybenzoate were used. The benzoic acid solution was prepared by trituration of $50 \mathrm{~g}$ of benzoic acid with $750 \mathrm{~mL}$ of propylene glycol using pestle and mortar. The mixture was transferred to a flask and purified water was added to obtain a volume of $1000 \mathrm{~mL}$. After that, $8 \mathrm{~g}$ of methyl hydroxybenzoate and $2 \mathrm{~g}$ of propyl hydroxybenzoate were triturated with $100 \mathrm{~g}$ of propylene glycol for the preparation of hydroxybenzoate solution. The solution was transferred to a flask. To prepare the suspension of ribavirin it is recommended that the manipulator uses safety glasses, protective clothing, gloves and face mask. All procedure should be performed in a flow hood, due to antiviral toxicity. The suspension was prepared by trituration into a mortar of $1.25 \mathrm{mg}$ powdered tragacanth, $2 \mathrm{~mL}$ of $90 \%(\mathrm{v} / \mathrm{v})$ alcohol and a little amount of distilled water was added until a homogeneous paste was obtained. Then, the contents of 20 capsules of ribavirin $200 \mathrm{mg}$ were added in the paste and triturated. The mixture was transferred to a flask which was added with $2 \mathrm{~mL}$ of the benzoic acid solution, $1 \mathrm{~mL}$ of the hydroxybenzoate solution and distilled water to obtain a final volume of $100 \mathrm{~mL}$. The suspension was stored in the refrigerator at $4{ }^{\circ} \mathrm{C}$ and for 28 days remained stable. The percentage of concentration was above $90 \%$ (Chan, Tong, Chow, 2004).

Many hospitalized patients are not able to swallow capsules and tablets. Most of these patients are children, elderly, bedridden and nasogastric tube users. The situational analysis to obtain the liquid oral dosage form is important for the pharmacist in the hospital (Glass, Haywo, 2006) (Figure 1).

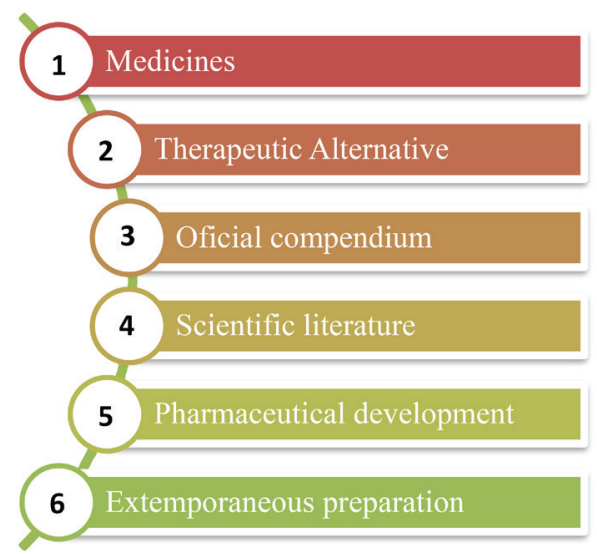

FIGURE 1 - Situational analysis to the preparation of extemporaneous oral liquid (Glass, Haywo, 2006).

The situational analysis to prepare the liquid oral dosage form should be carried out in the following situations (Glass, Haywo, 2006; Jackson, Lowey, 2010):
1 - Initially, the pharmacist must start from the principle that the prescribed drug is available in liquid oral dosage form (solution, drops, syrup) (Figure 1/ situation 1). In the absence of liquid oral dosage form, an alternative pharmaceutical form, as a dispersible tablet or suppository, may solve the problem (Figure 2). In the absence of these pharmaceutical forms, the alternative is the transformation of the pharmaceutical form. For some drugs in liquid oral form, the lack of clinical studies and safety information can compromise the patient safety. The extemporaneous preparation of liquid oral from solid oral and subsequent administration to the patient should be performed in hospital environment with supervision of a multidisciplinary group composed of doctors, nurses and pharmacists.

2 - In the absence of the prescribed medication, the multidisciplinary group must discuss the existence of a therapeutic alternative in liquid oral dosage form for the solution of the problem (Figure 1/situation 2). However, in some situations the drug is orphan (unique) and there are no therapeutic alternatives. In case liquid oral dosage form is not available, it is necessary to prepare extemporaneous liquid from solid oral dosage form.

3 - The search related to drugs in liquid oral form is performed in official compendia, such as pharmacopoeias and national formularies (Figure 1/situation 3). The most used are the Brazilian Pharmacopoeia (2010), Handbook of Extemporaneous Preparation: a guide to pharmaceutical compounding (Jackson, Lowey, 2010); National Formulary of Brazilian Pharmacopoeia (2012), Portuguese Galenic Formulary (2005) and Pediatric Pharmacopoeia (1998). These official compendiums report suggestions of liquid oral formulation with stability studies containing expiration date, storage conditions and packaging. This alternative should be investigated prior to the preparation of liquid oral formulation from tablet trituration or capsule opening, because such practice is not supervised by any health regulatory agency. The manipulation of liquid oral formulations prepared from tablets trituration or capsules opening should be performed considering the stability, incompatibilities, literature information and release forms such as controlled release. The use of tablets and capsules with modified release for the preparation of oral liquid formulations should be avoided.

4 - In the absence of liquid oral formulation in pharmacopoeias and formularies, the pharmacist can search for the formulations in the scientific literature (Figure 1/situation 4), such as books (Fernandez, Atienza, 2002; Jackson, Lowey, 2010; Jew et al., 2010), and scientific journals (Mcrorie, 1996; Nahata, 1999; Brion, Nunn, Rietour, 2003; Nunn, Williams, 2005; 
Glass, Haywood, 2013; Johohann, Mastroianni, 2016; Campbell, Vallejo, 2015; Mimouni, Van der Anker, 2015; Dijkers et al., 2017; Roque, 2017). A bibliographic research in database may indicate scientific articles that contain suggestions of formulation with stability study.

5 - In the absence of formulation and stability studies in the scientific literature, the pharmacist is challenged to develop the liquid oral formulation and the stability following scientific principles (Figure 1/ situation 5). The analysis of the following parameters must be checked: stability of the drug in the solvent (water, buffer or syrup), stability of the drug in relation to the environment (oxidation, photodegradation, and hydrolysis); the drug and excipient interactions (solvent, thickening agent, sweetener, colorant, complexing, antioxidant and preservative), incompatibilities between drug and packaging material composition (glass or plastic), and storage stability (light, temperature and humidity) (Jackson, Lowey, 2010). The ideal condition is the preparation of liquid oral form using the drug powder (Figure 2). In the impossibility of the drug powder acquisition, it is necessary to prepare the liquid oral formulation from the solid oral (tablet or capsule) by the pharmacist. It is necessary the technical knowledge of the formulation of tablet or capsule to prevent from the excipients in the solid form degrade the drug in the liquid oral formulation. Often, the tablet and capsule excipients do not degrade the drug, allowing the preparation of liquid oral formulation.

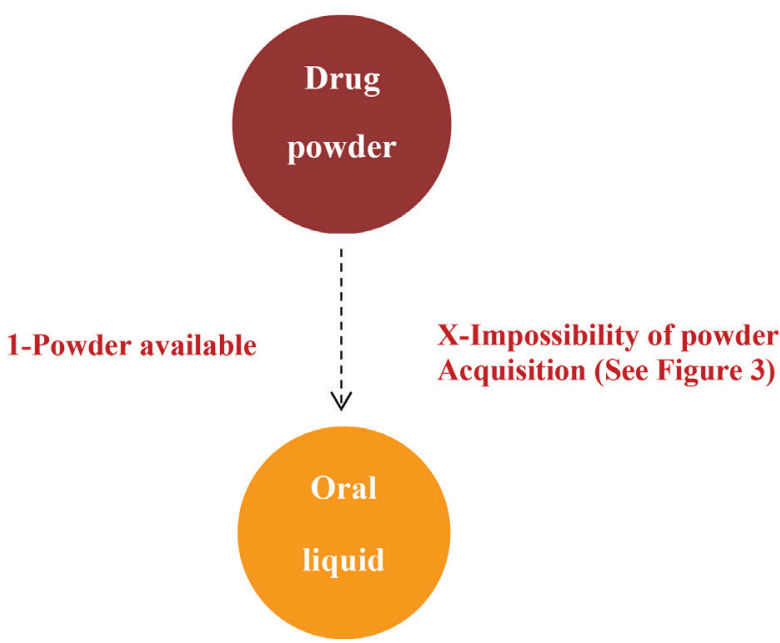

FIGURE 2 - Preparation of the oral liquid formulation from drug powder.

6 - When the development of the liquid oral formulation is infeasible due to instability of the drug in aqueous vehicle, the alternatives for the pharmacist involve the extemporaneous preparation of the liquid oral formulation from (Figure 1/situation 6) (Glass, Haywo, 2006; Jackson, Lowey, 2010; World Health Organization, 2011b): 6.1 - Tablet trituration and addition to vehicle (water, buffer and syrup) for dispersion (Figure 3); 6.2 - Capsule opening and addition to vehicle (water, buffer, syrup) for dispersion; 6.3 - Tablet trituration and addition to diluents such as lactose or starch to adjust the dosage and capsule filling. Subsequent extemporaneous preparation of the liquid oral formulation from capsule opening and addition of vehicle (water, buffer, syrup) for dispersion. A viable alternative is tablet trituration or capsule opening and subsequent addition to food or beverage. However, this practice is not recommended due to the drug-food interaction that may cause decreased absorption and bioavailability (Glass, Haywood, 2006; Jackson, Lowey, 2010).

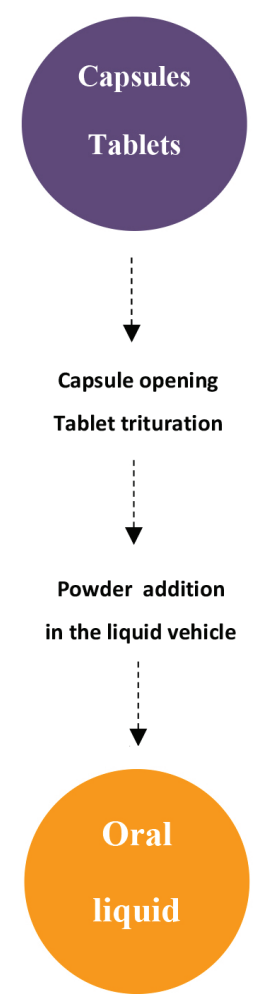

FIGURE 3 - Preparation of the oral liquid formulation from tablet or capsule.

The trituration of tablets or opening of capsules with modified release is not recommended (Table II).

Tablet trituration is permitted for tablets without functional coating. Tablets that contain gastro-resistant coat or with sustained release matrix should not be triturated, because this practice is dangerous and exposes the patients to health risk (Jackson, Lowey, 2010): 1 drug degradation resulting in low absorption and absence of pharmacological effect; 2 - immediate release of high 
doses and subsequent plasmatic concentration that exceeds the toxic concentration, resulting in adverse effects. Furthermore, addition of powder from tablet or capsule in a bottle with water to obtain a solution or suspension may generate an unpleasant taste to the patient, besides problems related to drug stability.

The use of sterile solutions or suspensions is not recommended (Figure 4), because the excipients may cause adverse effects when administered by oral route. Sterile solutions or suspensions may contain propylene glycol, which has a laxative activity when administered orally, example: diazepam injectable sterile solution (Garcia-Palop et al., 2016) and still, may contain polysorbate 20 and 80 , leading to renal dysfunction, and hepatomegaly (Cuzzolin, 2018). However, the preparation of oral solutions from sterile solutions or suspensions is feasible when the drug and the excipients are not irritant or toxic to the gastrointestinal mucosa, example: injection of vancomycin hydrochloride (Ensom, Decarie, Lakhani, 2010).

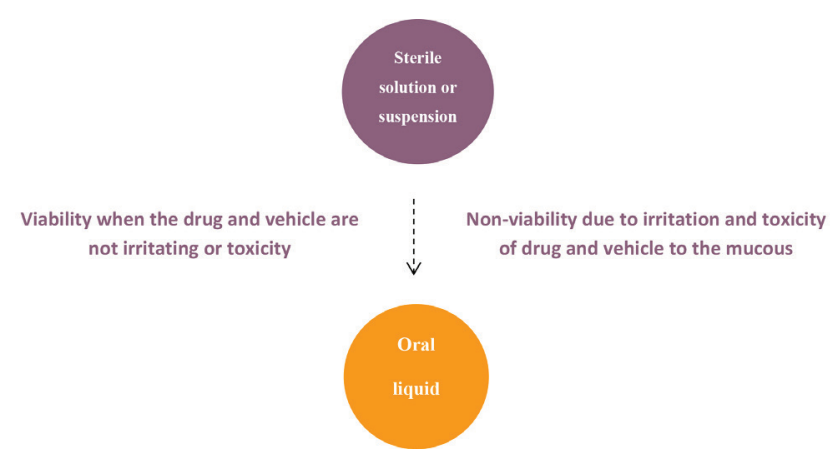

FIGURE 4 - Preparation of the oral liquid formulation from suspension or sterile solution.

\section{CONCLUSION}

The development of extemporaneous oral liquid in the hospital environment to the elderly, children, nasogastric tube and bedridden patients can be performed from the knowledge of incompatibilities, stability and toxicity of the drug in liquid oral form. In addition, information about the patient age and disease is important for the correct choice of vehicle for the liquid oral formulation. As discussed previously, it is not possible to administer to newborns many types of excipients, such as; sweeteners, preservatives and dyes. Solutions containing sugars and salts should not be administered to diabetic and hypertensive patients, respectively. The difficulty in swallowing by elderly, children, bedridden and nasogastric tube patients requires the administration of liquid oral formulations, which are often not available in the market. Any factor that compromises the stability of the drug in aqueous vehicle and consequently patient safety is a barrier to the development of the formulation. Thus, the preparation of extemporaneous liquid oral from solid oral dosage form is performed based on information from official compendium or scientific literature. This article of review is a guide containing information about the preparation and stability of extemporaneous oral liquid for use in hospital clinical practice.

\section{REFERENCES}

Alemon-Medina R, Chavez-Pacheco JL, Ramires-Mendiola B, Riviera-Espinosa L, Garcia-Alvares. Physicochemical stability of three generic brands of metformin in solution. Acta Ped México. 2014;35(2):94-99.

Allen LV, Erickson MA. Stability of acetazolamide, allopurinol, azathioprine, clonazepam, and flucytosine in extemporaneously compounded oral liquids. Am J Health Syst Pharm. 1996b;53(16):1944-49.

Allen LV, Erickson MA. Stability of alprazolam, chloroquine phosphate, cisapride, enalapril maleate, and hydralazine hydrochloride in extemporaneously compounded oral liquids. Am J Health Syst Pharm. 1998;55(18):1915-20.

Allen LV, Erickson MA. Stability of baclofen, captopril, diltiazem hydrochloride, dipyridamole, and flecainide acetate in extemporaneously compounded oral liquids. Am J Health Syst Pharm. 1996a;53(18):2179-84.

Allen LV. Topiramate $20 \mathrm{mg} / \mathrm{mL}$ oral suspension. US Pharm. 2017;42(5):46-7.

Brasil. Ministério da Saúde. Agência Nacional de Vigilância Sanitária. Formulário Nacional 2a .ed. Brasília: Anvisa; 2012.

Brasil. Ministério da Saúde. Farmacopeia Brasileira volume 2. Agência Nacional de Vigilância Sanitária. Brasília: Anvisa; 2010 .

Brion F, Nunn AJ, Rietour DA. Extemporaneous (magistral) preparation of oral medicines for children in European hospitals. Acta Paediatr. 2003;92(4):486-490.

Brown WJ, Buist NRM, Gepson HT. Fatal benzyl alcohol poisoning in a neonatal intensive care unit. Lancet. 1982;1(8283):1250. 
Buontempoa F, Morettona MA, Quirogad E, Chiappetta DA. Extemporaneous clobazam suspensions for pediatric use prepared from commercially available tablets and pure drug. Farm. Hospit. 2013;37(2):103-110.

Campbell GA, Vallejo E. Primary Packaging Considerations in Developing Medicines for Children: Oral Liquid and Powder for Constitution. J Pharm Sci. 2015:104(1):52-62.

Chan JP, Tong HHY, Chow AHL. Stability of extemporaneous oral Ribavirin liquid preparation. Int J Pharml Compounding. 2004;8(6):486-488.

Cuzzolin L. Neonates exposed to excipients: concern about safety. J Pediatr Neonat Individual Med. 2018;7(1):e070112.

Dijkers E, Nanhekhan V, Thorissen A, Marro D, Uriel M. Limited influence of excipients in extemporaneous compounded suspensions. Hospital Pharm. 2017;52(6):428-32.

Doningos JL. Medicamentos em crianças. Secretaria de Ciência, Tecnologia e Insumos Estratégicos/MS/FTN, 2010. [Acessado em: 10/09/2017]. Available: at: http://repositorio.unb.br/ bitstream/10482/12972/1/CAPITULO_MedicamentosCriancas. pdf.

Dysarz LP. Desenvolvimento e caracterização de uma formulação magistral líquida de captopril 0,5\%. [Master's Dissertation]. Rio de Janeiro: Faculdade de Farmácia, UFRJ; 2017.

Ensom MHH, Decarie D, Lakhani A. Stability of vancomycin $25 \mathrm{mg} / \mathrm{mL}$ in Ora-Sweet and water in unit-dose cups and plastic bottles at $4^{\circ} \mathrm{C}$ and $25^{\circ} \mathrm{C}$. Can J Hosp Pharm. 2010;63(5):366372 .

Ensom MHH, Decarie D, Lingertat-Walsh K. Stability of extemporaneously compounded Naproxen $25 \mathrm{mg} / \mathrm{mL}$ suspension in glass and plastic bottles and plastic Syringes. Can J HospPharm. 2015;68(6):489-491.

Ensom MHH, Decarie D. Stability of extemporaneously compounded Clonidine in glass and plastic bottles and plastic syringes. Can J Hosp Pharm. 2014;67(4):308-310.

Ensom MHH, Kendrick J, Rudolph S, Decarie D. Stability of propranolol in extemporaneously compounded suspensions. Can J Hosp Pharm. 2013;66(2):118-24.
Estevez P, Boscolo O, Quiroga E, Penuto RF, Buontempo F, Tripodi V, et al. Development and stability study of glibenclamide oral liquid paediatric formulations for the treatment of permanent neonatal diabetes mellitus. Eur J HospPharm. 2016;23(4):213-218.

European Medicines Agency. EMEA. Guideline on Pharmaceutical Development of Medicines for Paediatric Use. London, England; 2013.

Fernandez M, Atienza J. Formulación em Farmácia Pediátrica. Sevilha: AEF2; 2002.

Ferreira AO, Polonini AC, Silva SL, Patrício FB, Brandão MAF, Raposo NRB. Feasibility of amlodipine besylate, chloroquine phosphate, dapsone, phenytoin, pyridoxine hydrochloride, sulfadiazine, sulfasalazine, tetracycline hydrochloride, trimethoprim and zonisamide in SyrSpend ${ }^{\circledR}$ SF PH4 oral suspensions. J PharmBiomed Anal. 2016;118:105-112.

Firas Y, Kreidieh HÁ, Moukadem, Nagi SS. Overview, prevention and management of chemotherapy extravasation. World J Clin Oncol. 2016;7(1):87-97.

Formulário Galênico Português. Centro Tecnológico do Medicamento. Lisboa: Associação Nacional das Farmácias; 2005.

Freed AL, Silbering SB, Kolodsick KJ, Rossi DT, Mahjour M, Kingsmill CA. The development and stability assessment of extemporaneous pediatric formulations of Accupril. Int J Pharm. 2005;304(1-2):135-144.

Friciu M, Roullin VG, Leclair G. Stability of gabapentin in extemporaneously compounded oral suspensions. PLoS One. 2017;12(4):1-11.

Friciu M, Savji T, Zara S, Leclair G. Evaluation of stability of melatonin in extemporaneously compounded oral suspensions. J Pharm Practice Res. 2016a;46(1):28-33.

Friciu M, Zaraa S, Roullin VG, Leclair G. Stability of diazoxide in extemporaneously compounded oral suspensions. PLoS One. 2016b;11(10):1-12.

Garcia-Palop B, Movilla Polanco E, Cañete Ramirez C, Cabanas Poy MJ. Harmful excipients in medicines for neonates in Spain. Int J Clin Pharm. 2016;38(2):238-42. 
Glass BD, Haywood A. Liquid Dosage Forms Extemporaneously prepared from commercially available products - Considering New Evidence on Stability. J Pharm Pharm Sci. 2013;16(3):44155 .

Glass BD, Haywood A. Stability considerations in liquid dosage forms extemporaneously prepared from commercially available products. J Pharm Pharm Sci. 2006;9(3):398-426.

Golightly LK, Smolinske SS, Bennett ML, Sutherland EW, Rumack BH. Pharmaceutical excipients. Adverse effects associated with 'inactive' ingredients in drug products. Med Toxicol. 1988;3(2):128-165. (Part I) and 3: 209 240. (Part II).

Hailong Z, Jie M, Yayu H, Xiaoyan H, Jianfeng X, Akira Y, et al. Absorption enhancing effects of chitosan oligomers on the intestinal absorption of low molecular weight heparin in rats. Int J Pharm. 2014;466(1-2):156-162.

Hoefler R, Vidal JS. Administração de medicamento por sonda. Bol Farmacot. 2003;3-4:1-6.

Horn LW, Kuhn RJ, Kanga JF. Evaluation of the reproducibility of tablet splitting to provide accurate doses for pediatric population. J Pediatr Pharm Pract. 1999;9(4):38-42.

Hutchinson DJ, Johnson CE, Klein KC. Stability of extemporaneously prepared moxifloxacin oral suspensions. Am J Health-Syst Pharm. 2009;66(7):665-7.

Jackson M, Lowey A. Handbook of Extemporaneous Preparation. A Guide to Pharmaceutical Compounding. First ed. London (UK): Pharmaceutical Press; 2010.

Jew RK, Soo-Hoo W, Erush SC, Amiri E. Extemporaneous formulations for pediatric, Geriatric and Special Needs Patients. 3th ed. Bethesda MD: American Society for Health-Systems Pharmacists; 2010.

Johnson CE, Price J, Hession JM. Stability of norfloxacin in an extemporaneously prepared oral liquid. Am J Health-Syst Pharm. 2001;58(7):577-579.

Johohann RLBJRL, Mastroianni PC. Analysis of extemporaneous oral liquid from commercially available drugs in hospital. Braz J Pharm Sci. 2016;52(3):517-525.

Kiel JS, Bryant TJ, Le Vasseur RG, Thomas HG. Liquid formulations of celecoxib for oral administration. Patent No. 20160346300. US; A1, 2016.
Klovrzová S, Zahálka L, Kř́̌ž T, Zahálková O, Matysová L, Šklubalová Z, et al. Extemporaneous sotalol hydrochloride oral solutions for use in paediatric cardiology: formulation and stability study. Eur J HospPharm. 2016;23(1):33-37.

Li Q, Liu Z, Shamalatha K, Karen W, Niesha G, Poi MJ. Stability of extemporaneous erlotinib, lapatinib, and imatinib oral suspensions. Am J Health-System Pharm. 2016;73(17):1331-7.

Ma C, Decarie D, Ensom MHH. Stability of clonidine suspension in oral plastic syringes. Am J Health-Syst Pharm. 2014;71(15):657-61.

Malik A, Gorman G, Coward L, Arnold JJ. Stability of an extemporaneously compounded oral suspension of bosentan. HospPharm. 2016;51(5):389-395.

Martinho JF, Guerreiro MP, Simon A. O fraccionamento de comprimidos no ambulatório: implicações para a prática clínica. Rev Port Farmacoter. 2010;2:119-125.

Mcdevitt JT, Gurst AH, Chen Y. Accuracy of tablet splitting. Pharmacotherapy. 1988;18(1):193-7.

Mcrorie T. Quality drug therapy in children: formulations and delivery. Drug Inf J. 1996;30(4):1173-7.

Méndez EME, Antequera, Rodríguez-Rabadán J, Puebla GV, Pardo TJ, Gallego LV, et al. Formulaciones orales acuosas: una administración más segura para pediatría. Rev O F I L. 2006;16(4):15-28.

Mimouni FB, Van den Anker JN (editors). Neonatal Pharmacology and Nutrition Update. Pediatr Adolesc Med. Basel Karger. 2015;18:41-57.

Motwani SK, Isloor SP, Arora VK .Liquid dosage forms of isotretinoin. Patent No. 20170165217. US; A1, 2017.

Nahata MC, Morosco RS, Brady MT. Extemporaneous sildenafil citrate oral suspensions for the treatment of pulmonary hypertension in children. Am J Health Syst Pharm. 2006;63(3):254-257.

Nahata MC, Morosco RS, Trowbridge JM. Stability of dapsone in two oral liquid dosage forms. Ann Pharmacother. 2000;34(7/8):848-850.

Nahata MC, Morosco RS. Stability of tiagabine in two oral liquid vehicles. Am J Health-Syst Pharm. 2003;60(1):75-77. 
Nahata MC. Lack of pediatric drug formulations. Pediatric. 1999;104(3):607-609.

Nunn T, Williams J. Formulation of medicines for children. Br J Clin Pharmacol. 2005;59:674-676.

Olguín HJ. Extemporaneous suspension of Propafenone: Attending lack of pediatric formulations in Mexico. Pediatr Cardiol. 2008;29(5):1077-81.

Paediatric Pharmacopoeia. Royal Children's Hospital Melbourne and Leicester. Royal Infirmary Children's Hospital. London: WB Saunders Company Ltd.; 1998.

Paradiso LM. Crushing or altering medications: what's happening in residential aged-care facilities? Aus J Ageing. 2002;21(3):123-127.

Perera G, Greindl M, Palmberger TF, Bernkop-Schnürch A. Insulin-loaded poly(acrylic acid)-cysteine nanoparticles: stability studies towards digestive enzymes of the intestine. Drug Deliv. 2009;16(5):254-60.

Pinto S, Barbosa CM. Medicamentos manipulados em pediatria, estado atual e perspectivas futuras. Arquivos de Medicina. 2008;22(2/3):75-84.

Polonini HC, Silva SL, Almeida TR, Brandão MAF, Ferreira AO. Compatibility of caffeine, carvedilol, clomipramine hydrochloride, folic acid, hydrochlorothiazide, loperamide hydrochloride, methotrexate, nadolol, naltrexone hydrochloride and pentoxifylline in SyrSpend SF PH4 oral suspensions. Eur J Hosp Pharm. 2016a;23(6):352-358.

Polonini HC, Silva SL, Cunha CN, Brandão MAF, Ferreira AO. Compatibility of cholecalciferol, haloperidol, imipramine hydrochloride, levodopa/carbidopa, lorazepam, minocycline hydrochloride, tacrolimus monohydrate, terbinafine, tramadol hydrochloride and valsartan in SyrSpend ${ }^{\circledR}$ SF PH4 oral suspensions. Pharmazie. 2016b;71(4):185-191.

Pramann LA, Davidow LW, Haandel L, Funk RS. Development of extemporaneously compounded Aripiprazole oral suspensions for use in children. Int J Pharm Compd. 2016;20(3):257-261.

Prohotsky DL, Juba KM, Zhao F. Formulation and stability of an extemporaneously compounded oral solution of chlorpromazine HCl. J Pain Palliat Care Pharmacother. 2014;28(4):367-70.
Provenza N, Calpena AC, Mallandrich M, Pueyo M, Clares B. Design of pediatric oral formulations with a low proportion of methadone or phenobarbital for the treatment of neonatal abstinence syndrome. Pharm Dev Technol. 2016;21(6):775-62.

Rasgado R. Interações entre medicamentos e alimentos. Centro de Farmacovigilância da UNIFAL - CEFAL, n. 2, 2009. [cited 2017 Sep 11] Available at: http://www.unifalmg.edu.br/cefal/ files/file/boletim $\% 20$ n $\% 20 \% 2002$.pdf.

Rebecca White and Vicky Bradnam. Handbook of Drug Administration via Enteral Feeding Tubes. Third ed. London: Pharmaceutical Press; 2015.

Romero RM, Corpas MV, Medina MDCG, Peña CG, Romero AC, Guardia AVR, et al. Extemporaneous preparation of oral liquid formulation of capecitabina. Eur J Hosp Pharm. 2016;23(S1):A1-262.

Roque F. Paediatric medicines: formulation considerations. Arch Pharm Pharma Sci. 2017;1:24-27.

Santoveña A, Charola I, Suárez-González J, Teigell-Pérez N, García-van Nood S, Soriano M. Development of a novel physico-chemically and microbiologically stable oral solution of flecainide for pediatrics. Pharm Dev Technol. 2016a;23:1-29.

Santoveña A, Suarez-Gonzalez J, Martın-Rodrıguez C, Farina JB. Formulation design of oral pediatric Acetazolamide suspension: dose uniformity and physico-chemical stability study. Pharm Dev Technol. 2016b;22(2):191-197.

Schlatter J, Bourguignon E, Majoul E, Kabiche S, Balde I-B, Cisternino S. Stability study of oral pediatric idebenone suspensions. J Pharm Dev Tech. 2017;22(2):296-9.

Schlatter J, Cisternino S. Stability of warfarin sodium flavoured preservative free oral liquid formulations. Eur J Hosp Pharm. 2017;1-4.

Silva LD, Lisboa CD. Consequência da interação entre nutrição enteral e fármacos administrados por sondas: uma revisão integrativa. Cogitare Enfer. 2011;16(1):134-40.

Smith AD, Rempel G, Szeitz A, Klassen TL, Ensom MHH. Vancomycin $50 \mathrm{mg} / \mathrm{mL}$ Suspension in Oral Syrup: Stability in Plastic Bottles and Syringes at 2 Temperatures. Can J Hospital Pharm. 2017;70(3):247-9. 
Song Y, Chin ZW, Ellis D, Lwin EMP, Turner S, Williams D, Garg S. Stability of an extemporaneously compounded minoxidil oral suspension. Am J Health-Syst Pharm. 2018;75(5):309-315.

Sosnowska K. Stability of extemporaneous enalapril maleate suspensions for pediatric use prepared from commercially available tablets. Acta Pol Pharmaceut - Drug Res. 2009;66(3):321-326.

Tan LK, Thenmozhiyal JC, Ho PC. Stability of extemporaneously prepared saquinavir formulations. J Clin Pharm Ther. 2003;28(6):457-463.

Thompson KC, Zhao Z, Mazakas JM, Beasley CA, Reed RA, Moser CL. Characterization of an extemporaneous liquid formulation of lisinopril. Am J Health Syst Pharm. 2003;60(1):69-74.

Thomson K, Hutchinson DJ, Chablani L. Stability of extemporaneously prepared cinacalcet oral suspensions. Am J Health-Syst Pharm. 2018;75(9):e236-e240.

Vanden Bussche HL, Johnson CE, Fontana EM, Meram JM. Stability of levofloxacin in an extemporaneously compounded oral liquid. Am J Health-Syst Pharm. 1999;56(22):2316-2318.

Vossen AC, Velde I, Meiracker AH, Nagel BCH, Koch BCP, Vulto AG, et al. Bioequivalence study of a newly developed oral solution of amlodipine and commercial tablets after single-dose administration in healthy volunteers. Int J Clin Pharmacol Ther. 2016;54(1):65-72.

Willians NT. Medication administration through enteral feeding tubes. Am J Health Syst Pharm. 2008;65(24):2347-57.
Winiarski AP, Infeld MH, Tscherne R, Bachynsky M, Rucki R, Nagano-Mate K. Preparation and stability of extemporaneous oral liquid formulations of oseltamivir using commercially available capsules. J Am Pharm Assoc. 2007;47(6):747-755.

Woods DJ. Extemporaneous formulations - problems and solutions. Paediatr. Perinat. Drug Therapy. 1997;1:25-29.

World Health Organization. WHO. Development of paediatric medicines: points to consider in formulation. Draft annex $46^{\mathrm{TH}}$ report of the WHO expert committee of specifications for pharmaceutical preparations. Geneva, Switzerland: WHO Press; 2011a.

World Health Organization. WHO. Provision by health-care professional of patient-specific preparations for children that are not available as authorized products-points to consider. 2011. Working document QAS/11.399/Rev.1. Geneva, Switzerland: WHO Press; $2011 b$.

Yamreudeewong W, Dolence KE, Pahl D. Stability of two extemporaneously prepared oral metoprolol and carvedilol liquids. Hospital Pharm. 2006;41(3):254-259.

Zahálka L, Klovrzová S, Matysová L, Šklubalová Z, Solich P. Furosemide ethanol-free oral solutions for paediatric use: formulation, HPLC method and stability study. Eur J Hosp Pharm. 2017;1-6.

Zaid AN, Assali M, Zalmout S, Bashee A. Compounding and stability evaluation of atorvastatin extemporaneous oral suspension using tablets or pure powder. Eur J Hosp Pharm. 2016;1-5.
Received for publication on $06^{\text {th }}$ May 2018 Accepted for publication on $17^{\text {th }}$ August 2018 